\title{
The Market Response to Exploration, Resource and Reserve Announcements by Mining Companies: Australian Data ${ }^{1,2}$
}

\author{
Ron Bird $^{\mathrm{a}}$ \\ Matthew Grosse ${ }^{\mathrm{b}}$ \\ Danny Yeung
}

\section{The Paul Woolley Centre@ UTS \\ Working Paper Series 7 April 2010}

\footnotetext{
${ }^{a}$ Paul Woolley Centre for the Study of Capital Market Dysfunctionality, UTS

${ }^{\mathrm{b}}$ Graduate student, University of Technology Sydney (UTS)
}

Draft: January, 2010

\begin{abstract}
This paper is the first to conduct an event study on the market response to exploration, resource and reserve announcements made by mining firms. Results from an event study using a matched firm approach that suggest that markets react positively to both the exploration and the resource announcements at the time of their release but find information value in the reserve announcements possibly because all of the information in these announcements have been anticipated by the market. In fact, there is evidence to suggest a high level of anticipation of all three types of announcements which should be a matter of concern for the regulators. The other major surprising finding in the study is that in every instance the market seems to have been overly enthusiastic about the announcements, as share prices turns down almost immediately afterwards and trends downward for an extended time. This leaves open the question as to why does the market get them so horribly wrong.
\end{abstract}

\footnotetext{
${ }^{1}$ Address for correspondence. ron.bird@uts.edu.au +61 (0)2 95147777

${ }^{2}$ We wish to acknowledge the generous support of the Paul Woolley Centre at UTS, without which this work would not have been possible.
} 


\section{The Market Response to Exploration and Reserve Announcements by Mining Companies: Australian Evidence}

A large body of work dating back over 40 years exists that applies event study methodology to determine the market response to numerous different corporate announcements including earnings, dividend and mergers. These studies have generally found that the announcements have significant immediate impact on pricing which is commonly followed by what has come to be known as a post-announcement drift. Given that such studies by now can be counted in their thousands, it is an anomaly that such analysis has not been extended to announcements relating to the exploration activities of mining companies. This paper proposes that estimated reserves are the primary source of fundamental share valuation for many mining and exploration companies as they provide the best available insight into the company's future profitability. Thus, the focus of this paper is on using event study methodology to evaluate the way that the market reacts to important announcements.

The results reported in this paper are of interest from several perspectives. First, they represent the first attempt at reporting on how the market reacts to exploration announcements by mining companies. Second, given the large amount of equity funds flowing into the exploration sector amidst rising commodity prices, understanding price reactions to exploration announcements may assist these investors to better understand the potential of their investments. Third, a finding of nonzero after-announcement excess returns would call into question the informational efficiency of the market. Fourth, from an investor's viewpoint, the existence of price patterns may present opportunities for active trading strategies to produce superior returns.

Announcements are designated as falling into three categories which follow the sequence of developing a mining project: exploration, resource and reserves. In the case of both the exploration and resource announcements, there are abnormal returns accumulated of between $2.5 \%$ and $3.0 \%$ over the period extending from 30 trading days before the announcement to the day of the announcement. This confirms that such announcements are good news for the market which actually anticipates about $50 \%$ of the information content of the announcement in advance of its release. The day after the release of the exploration and resource, the market begins to reassess whether they were indeed good news with the returns turning negative and continuing so for an extended period. Further analysis showed that the poor post-announcement performance was largely confined to the junior mining companies with the established miners retaining most of the abnormal returns accumulated during the pre-announcement and announcement periods. In the case of the reserve announcements, the abnormal return accumulated during the pre-announcement and announcement periods accumulated to around $4.0 \%$ with this time with almost the entire amount being anticipated in advance of the announcement. Again we have an almost instant turnaround from the day after the announcement which extends for the next 60 trading days and more than wipes out the $4.0 \%$ previously accumulated. This time it is the well established miners that perform by far the worst with junior minors largely holding on the abnormal returns previously accumulated.

The structure of the paper is as follows. Section 2 presents information on the exploration and mining industry, its importance and the motivation behind this study, Section 3 summarises the limited capital market publications dealing with the mining industry and for comparative purposes, a brief summary of event studies of earnings announcements. In Section 4 the data sources and methodology used in this study are discussed. Section 5 presents the empirical results of how the market reacts to exploration, resource and reserve announcements. Section 6 provides us with the opportunity to summarise the results and suggests opportunities for further work. 


\section{Section 1: Background on Mineral Explorations}

With commodity prices and global mineral demand increasing, we saw rapid growth in exploration during the expansionary period from 2002 to 2008 (Hellbling and Blackman 2008). Figure 1 shows the growth and magnitude of exploration budgets worldwide over the period from 1991 to 2009, and demonstrates how it is closely related to the level of commodity prices.

Figure 1: Estimated Global Nonferrous Exploration Budgets and Relative Metals Prices, 1989 - 2009

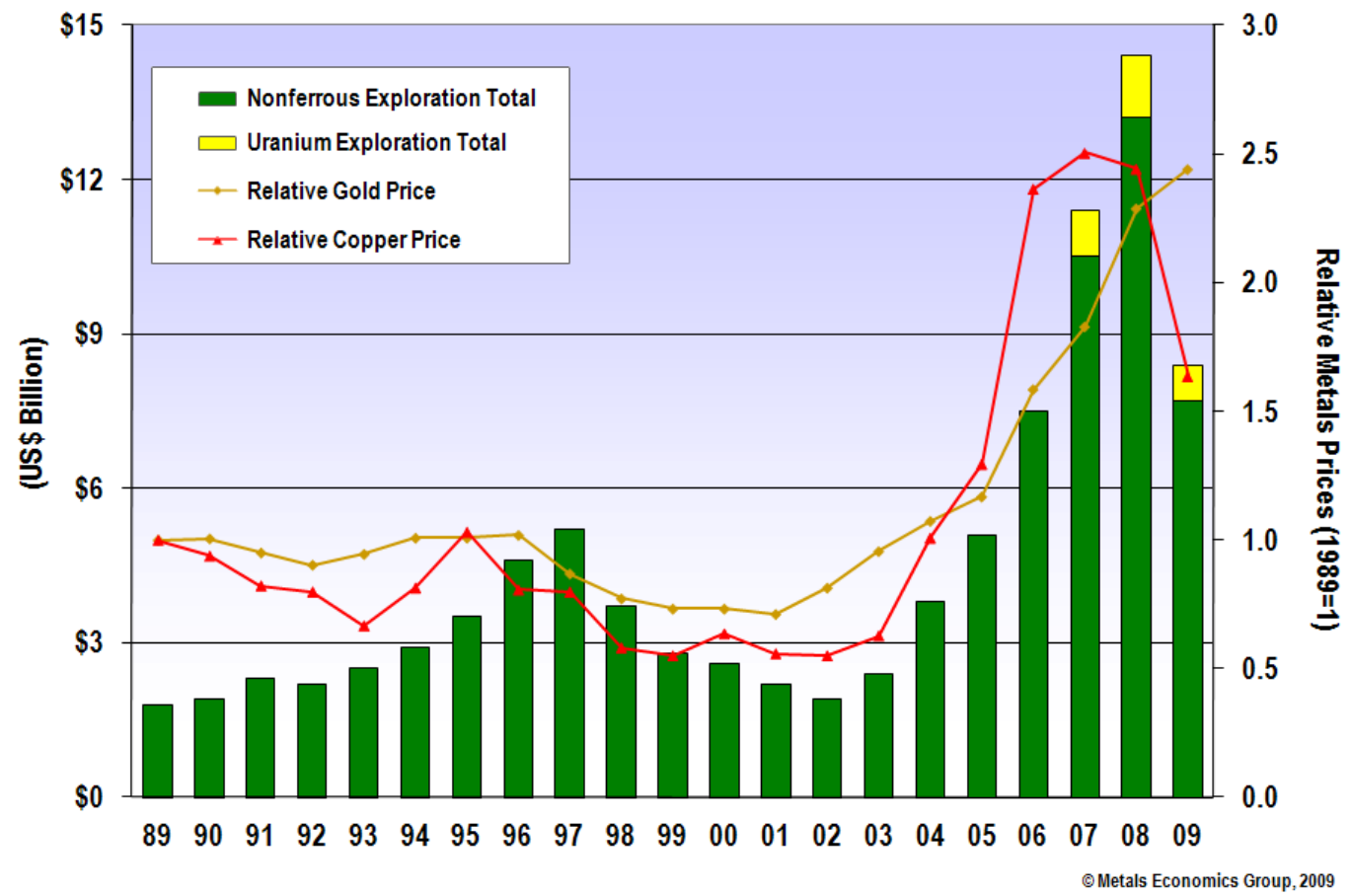

The worldwide boom in commodity prices and exploration expenditure has been particularly important for Australia which is home to over $14 \%$ of the world's exploration expenditure as shown in Figure 2 (Metals Economics Group, 2009). With many listed companies conducting exploration overseas while being listed on the ASX, it is possible that well over $20 \%$ of the world's exploration budget amounting to US $\$ 2.5 B$ is being spent in Australia and/or by Australian companies.

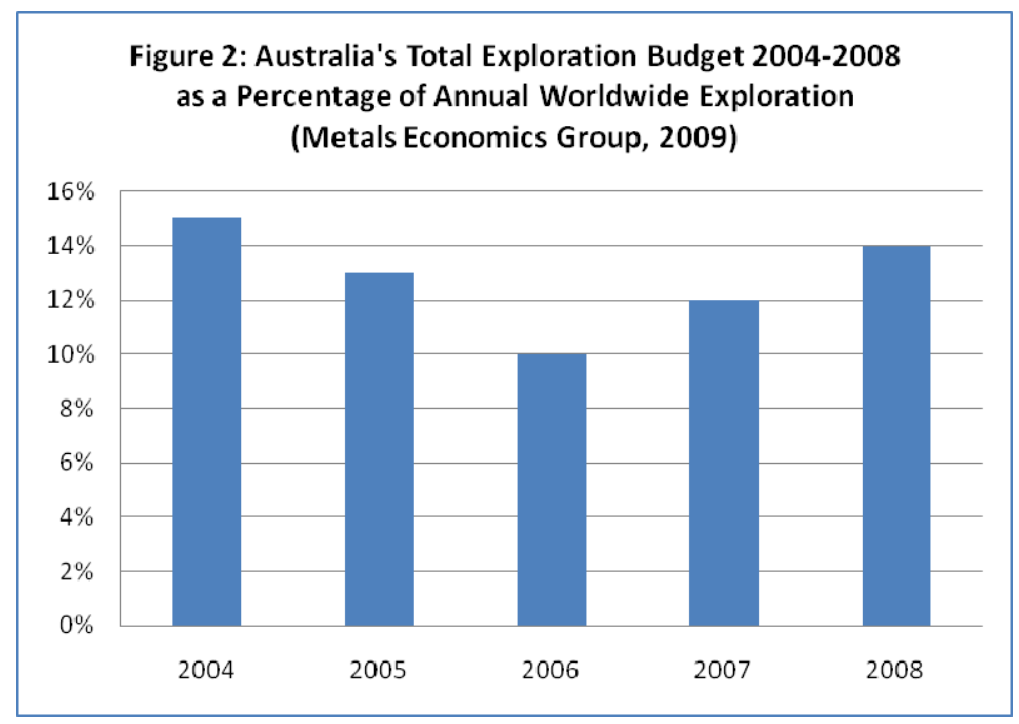


With the significant majority of exploration research being funded by equity markets as shown in Figure 3 (Metal Economics Group 2009), Australian capital market researchers should be particularly interested in how the market values these exploration projects, and how it responds to their success or failure. The Australian Stock Exchange (ASX) consists of over 1700 listed companies, of which nearly 800 are Mining, Energy and Exploration companies (ASX, 2009), representing over $20 \%$ of the total capitalisation of the ASX. Along with the Toronto Stock Exchange, it is the largest market for listed mining and exploration companies in the world (Metal Economic Group 2009). The Australian mining industry was the largest industry contributor to Australian EBITDA, earning \$48.9bn in 2007-2008 with $15.7 \%$ of all market earnings being reported by mining companies (ABS 2008).

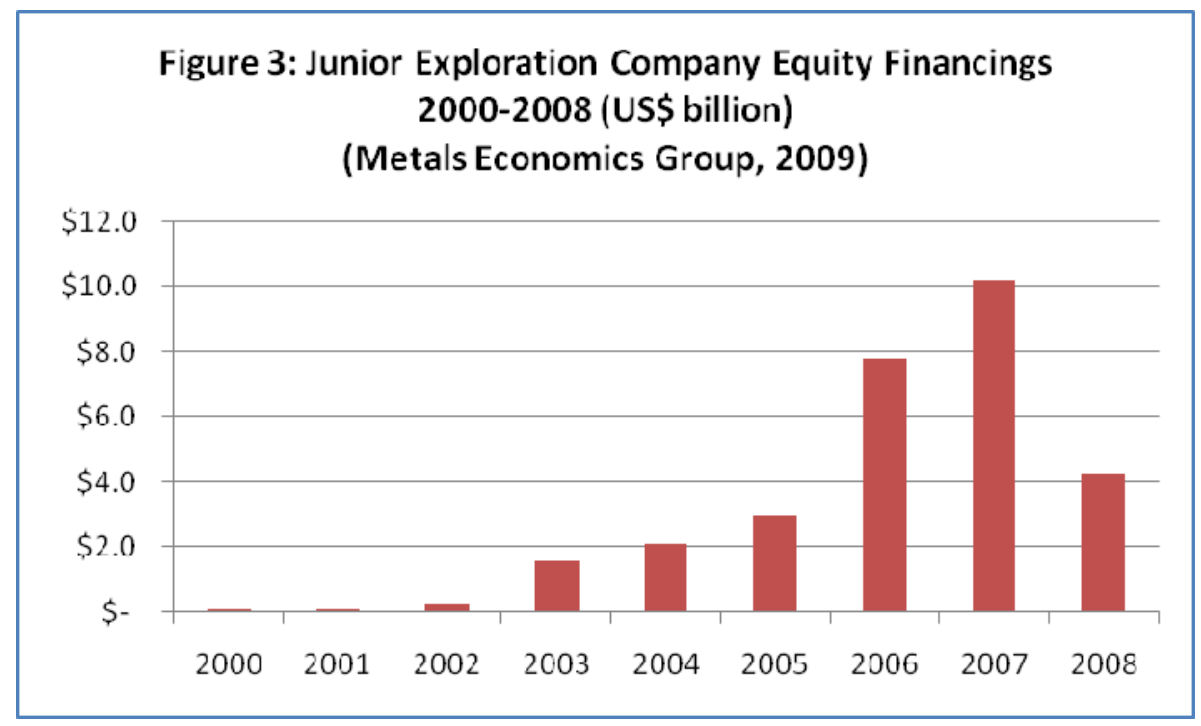

With over US \$25 billion in equity raised for mineral exploration since 2004, the importance of how these firms perform in the wake of announcing exploration success is becoming increasingly relevant to market participants. This study will explore general trends in the price response of firms when announcing news regarding exploration results, and appears to be particularly timely, given the recent interest of overseas corporations and governments in buying into Australian mining companies.

\section{Section 2: Literature Review}

\subsection{Exploration and Mining Studies}

A review of the literature reveals a surprisingly small number of market-based studies using data drawn from the mining industry and no studies that have used event study methodology as in this study to examine the market reaction to exploration and reserve announcements by mining companies. Czernkowski and Ferguson (2006) suggest this lack of academic research may be due to the asymmetric properties of information within the industry and the lack of domain knowledge among capital market researchers. They test and find some weak evidence to support that the achievement of milestones from initial feasibility studies to financing culminating in production represents points of asymmetric information resolution for small mining firms ${ }^{1}$. O'Shea et al (2008) found that the more frequent the disclosures by small Australian mining companies, the greater the volatility of

\footnotetext{
${ }^{1}$ Brown et al (2008) found that equity raisings by mining companies had a less negative impact on their share price than it did for non-mining companies.
} 
their shares. This led them to conclude that disclosure was often used for self-promotion rather than the provision of information.

There would appear to be a fair amount of contagion in the share prices of mining companies. Ferguson and Crockett (2003) found that a discovery by one miner impacted the market value of miners with nearby leases. The ones impacted most were those that got most press coverage at the time but these subsequently were the greatest under-performers. Brown and Burdekin (2000) using event study methodology found that the failure of Bre-X in 1997 resulted in a very large drop in value across the whole Canadian mining sector but particularly for small miners. Magness (2009) also used event study methodology to examine the impact of an environmental accident at the Placer Dome mine on the market value of other Canadian mining companies. She finds the impact of the disaster caused an overall decline in the value of mining companies but this was less for companies with management dedicated to environmental management.

Consistent with the growth in equity financings for exploration firms in recent years (see Figure 3), Kreuzer, Etheridge \& Guj (2007) found over 100 junior mining firms ${ }^{2}$ were listed as IPO's on the ASX during the period from 2004 to 2006. The overall listing value of these companies was over $\$ 500$ million even though less than $30 \%$ of the companies had yet to make any exploration announcements regarding possible resource levels within their exploration tenements. Despite the increase of equity funds flowing into exploration projects in recent years, the fundamental characteristics defining successful exploration projects are not well known. A study by Kennedy $(1996,1997)$ of the performance of 220 junior explorers listed on the ASX between 1983 and 1987 isolated ingredients important to the success of Australian companies as including: sufficient capital, technical and financial expertise in the board and exploration success. How (2000) found that the Australian IPOs for mining companies during the period from 1979 to 1990 were underpriced on average by more than $100 \%$ and that their longer term performance was superior to non-mining companies.

The most voluminous literature on mining company disclosure undoubtedly lies in studies of the accounting reporting requirements for oil and gas companies. Up to 19977, oil and gas companies had the option to capitalise all of their exploration expenses or only those where the exploration proved successful. However, then the Financial Accounting Standards Board (FASB) changed to requiring companies to only capitalise only successful efforts. At the time there was a concern that the earnings would suffer for companies that had previously been using the full cost method and that this found find evidence to support that the smaller mining companies who has been the major users of the full cost method were most impacted by the accounting change. In 1978, the Securities and Exchange Commission (SEC) required oil and gas companies to provide supplementary information in their financial statements on the valuation of their proved oil and gas reserves. Magliolo (1986), and Harris and Ohlson (1990) found weak association between security prices and this additional disclosure suggesting that it contained little in the way of information. Clinch and Magliolo (1992) propose that this weak association is due to investors putting much greater weight on the less encompassing but more substantive production numbers, indicating an unwillingness to act on estimates provided by management. In contrast Boone (1998) found that the bid-ask spread for oil and gas companies decreased after they were required to place a value on their reserves suggesting that investors saw this as reducing the asymmetry in the information available to the market.

\footnotetext{
${ }^{2}$ Junior mining companies have no mining operations and so their sole activity is exploration. They are almost totally reliant on capital markets for fund raising
} 


\subsection{An Overview of Earnings Announcement Studies}

Although the evidence on the market impact of announcements by mining companies is sparse, that which is available suggests that the market finds it difficult to interpret the price implications of the information that is provided. Czernkowski and Ferguson (2006) suggest that the successful evaluation of exploration and mining firms requires that equity analysts go beyond their comfort zone of regular financial statements and predictable earnings signals, and into the analysis of complex geological reports that they may be unable to effectively decipher, leaving them incapable of effectively valuing these firms, thus relevant public signals released by mining firms may not be successfully assimilated into the market price by investors. Indeed in our sample, less than half of the companies making exploration announcements have any revenues, much less profits, so traditional valuation tools are not an option. It is hypothesised in this paper that the most important corporate announcement made by exploration and mining firms to the market involves the release of information relevant to the estimation of their mineral resources and ore reserves. It is these announcements that provide insights into the future asset base of the firm and so its potential to generate earnings. As such the reserve announcements of mining companies are akin to earnings announcements for non-mining firms in terms of the information that they provide to facilitate a valuation of the firm.

In this study we are going to examine the market impact attributable to exploration announcements of mining companies over a period from six weeks before the announcement to 12 weeks after. This enables us to examine the reaction to the announcements during the period prior to the announcement, at the time of the announcement and during the period subsequent to the announcement. For comparison purposes, we will review the evidence on the market reaction during these same three periods as it can then provide us with a benchmark against which to compare our findings for mining companies.

Ball and Brown (1968) was both the first test that evaluated the market reaction to earnings announcements and the first study to use event study methodology. Using monthly data, they examined the market response to both positive and negative earnings surprise announcements over the period from 1957 to 1965. They found that prices did react to the announcement in the expected fashion but that most of the information content of the announcement had been impounded in the price over the previous 12 months. Further, they observed that there was some evidence to suggest that that the share price was still adjusting to the information up to two months after its release. This has come to be known as the post-announcement earnings drift (PEAD).

Following the Ball and Brown study, a plethora of papers have confirmed the impact that unexpected earnings has on a company's share price at the time of the announcement using data from different countries and/or different frequencies of reporting (e.g. Watts, 1978; Falk and Levy, 1989, Meek, 1991; Brown 1970; Firth 1981; Benos and Rockinger, 2000; How, 2000). However the worrying feature of the Ball and Brown study that has subsequently gained most attention is the PEAD (Ball, 1978) which is thoroughly reviewed in Foster et al (1984). Numerous studies have attempted to provide an explanation for its existence without a great deal of success (Bernard and Thomas, 1989 and 1900; Bartov et al, 2000; Chordia et al, 2009). Fama (1998) acknowledges the PEAD as one of a small number of outstanding market anomalies and Schwert (2003) observed that unlike a number of other suppose anomalies, it has remained robust since its first discovery. The other aspect of the Ball and Brown findings that has received much less attentions has been the pre-earnings announcement drift. Ball and Brown put it down to the fact that much information pre-dates the announcement of annual earnings and so it is not surprising that investors react to this information rather than wait for the release of annual earnings. However when researchers looked at quarterly earnings, the drift was still apparent 
suggesting that there may be some market anticipation of earnings announcements which cannot be explained by publicly available information (Foster et al, 1984). In more recent times we have seen much more activity by companies to guide the earnings expectations of the market which has reduced the level of earnings surprises and seemingly reduced the impact of earnings announcements on market prices (Soffer et al, 2000; Soffer, 2001).

In summary, the evidence on earnings announcements would suggest that we would observe a reaction to the unexpected component of any earnings release which is likely to be followed by a drift for several months after the announcement and preceded by some "anticipation" of the unexpected earnings. It is difficult to observe the undetected component of the exploration announcements by mining companies to see how the market reaction to these announcements compares to that discussed above for earnings announcements.

\section{Section 3: Data and Methodology}

\subsection{Definition of the Event}

Countries that rely on private investors to find and exploit their mineral resources need reliable reporting indicators of their investment attractiveness (Jara et al. 2008); Australia being one of the world's largest private equity markets for exploration firms has a well structured and reliable system for the reporting of exploration results to investors. As the reporting of exploration results is announced in a standardised way, the announcements exhibit properties that make the use of an event study methodology appropriate.

The reporting framework that governs announcements made by ASX listed firms requires that companies operate under a regime of continuous disclosure. Under continuous disclosure, once an entity becomes aware of any information concerning it that a reasonable person would expect to have a material effect on the price or value of the entity's securities, the entity must immediately inform the ASX of this information (ASX 2009A). Numerous disclosures are made to the ASX and released to the market each day with a subset of these disclosures being tagged as "price sensitive” (Dumay and Tull 2007). Of particular interest to this paper, is a subsection of these ASX price sensitive announcements, specifically announcements made to ASX by Australian mining companies in accordance with the code drawn up by the Joint Ore Reserve Committee ${ }^{3}$ (the JORC code).

The JORC ${ }^{4}$ code was first released in 1989, with the latest edition being finalised and included in the ASX listing rules on the 17th December 2004. Since that date ASX listing rule chapter 5, appendix 5A requires listed companies to prepare exploration results, mineral resources and ore reserves estimates in compliance with the JORC code. This code states that a company must disclose to the market any relevant information concerning a mineral deposit that could materially influence the economic value of that deposit to the ASX, and a company must promptly report any material changes in its mineral resources or ore reserves (JORC 2004). Thus these announcements being made to the market should contain information relevant to the pricing of the underlying securities.

\subsection{Sample Period}

The dataset used in this study uses JORC compliant exploration, resource and reserve announcements from ASX listed firms between the $17^{\text {th }}$ December 2004 and $31^{\text {st }}$

\footnotetext{
${ }^{3}$ This is a joint committee of the Australian Institute of Mining and metallurgy, the Australian Institute of Geoscientists and the Mineral Council of Australia.

${ }^{4}$ A recent review of the adherence to the JORC Code undertaken by the ASX found 6\% non-compliance with the main failure being the absences of
} 
December 2008, this sample period is chosen to comply with the current regulatory system, as the pre 2004 JORC code provided no framework for reporting exploration results.

\subsection{Data Collection}

The JORC compliant announcements were obtained from SIRCA using a company announcement (Signal G) keyword search over the 2004-2008 period. The keyword used was JORC as each announcement is required to include a statement stating that the report has been compiled in a JORC compliant manner. Over 15,000 announcements were recovered using JORC as the keyword, many which were irrelevant to this study, such as annual reports, quarterly reports and various other corporate reports. By systematically looking through the announcements, irrelevant corporate reports not related to exploration or resource announcements were removed, and the remaining statements were categorised into three samples: Exploration Results, Mineral Resource and Ore Reserves. These categories are clearly defined in the JORC code, as explained in Figure 4. As the three stages are unique stages in the exploration lifecycle, it is important that they each be studied as separate corporate events.

Figure 4: The 3 levels of mining firm announcements (Source: JORC 2004)

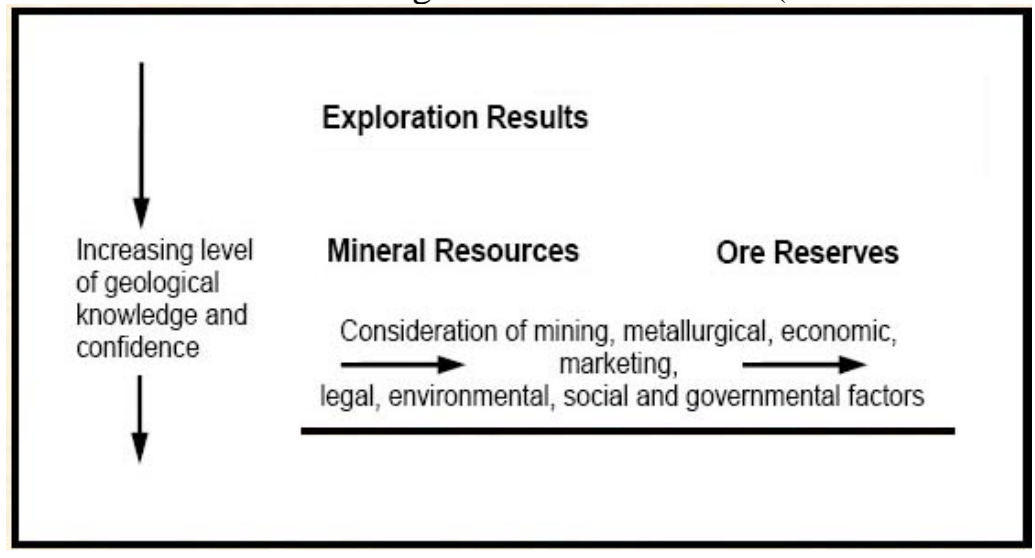

\subsection{Exploration Results}

Exploration Result announcements are defined by the JORC Code as "including data and information generated by exploration programmes that may be of use to investors" (JORC, 2004, p. 8). The available data available is generally insufficient to allow any reasonable estimates of mineral resources. Examples of Exploration Results include results of outcrop sampling, assays of drill-hole intercepts, geochemical results and geophysical survey results.

Using the JORC definition of Exploration results, a sample of 1285 exploration announcements was found consisting of drilling results, assays and other eligible announcements, with announcements coming from 354 unique firms. The frequency of exploration announcements as shown in Table 1 was found to be increasing over the sample period. The increasing frequency of exploration announcements is consistent with previous evidence cited that the level of exploration tends to increase with commodity prices (Mohn 2008). 


\section{Table 1:}

Number of announcements made each year throughout the sample period.

\begin{tabular}{rrrr}
\hline Year & Exploration Sample & Resource Sample & Reserve Sample \\
\hline $\mathbf{2 0 0 5}$ & 151 & 109 & 17 \\
$\mathbf{2 0 0 6}$ & 288 & 132 & 17 \\
$\mathbf{2 0 0 7}$ & 418 & 180 & 26 \\
$\mathbf{2 0 0 8}$ & 428 & 209 & 30 \\
Total & $\mathbf{1 2 8 5}$ & $\mathbf{6 3 0}$ & $\mathbf{9 0}$ \\
\hline
\end{tabular}

As Exploration results are the first stage in the discovery of a minable resource, the firms making these announcements can often be characterised as having low market capitalisations, poor liquidity and are relatively newly listed firms. Table 2 shows that the median market capitalisation of firms announcing exploration results is a tiny $\$ 33.1 \mathrm{~m}$, while Table 3 shows the medium number of days on which a sample company trades is 67 days during the 91 day event window. The findings in this paper are supported by Kreuzer et al. (2007) who found that the average market capitalisation of 179 Australian exploration and mining IPO’s undertaken between 2001 and 2006 was only $\$ 4 \mathrm{~m}$, with many of these Exploration Announcements being made by companies early in their life cycle.

Table 2

Market Capitalisation of firms on the day of their announcement

\begin{tabular}{ccccc}
\hline Observations & $\begin{array}{c}\text { Exploration } \\
\text { Sample }\end{array}$ & $\begin{array}{c}\text { Resource } \\
\text { Sample }\end{array}$ & $\begin{array}{c}\text { Reserve } \\
\text { Sample }\end{array}$ & $\begin{array}{c}\text { ASX300 (as at } \\
\mathbf{1 3 / 1 2} / \mathbf{2 0 0 8})\end{array}$ \\
Min & 1285 & 630 & 90 & 300 \\
Max & $\$ 1.2 \mathrm{~m}$ & $\$ 1.8 \mathrm{~m}$ & $\$ 7.77 \mathrm{~m}$ & $\$ 25.7 \mathrm{~m}$ \\
Average & $\$ 183.3 \mathrm{~m}$ & $\$ 1061.3 \mathrm{~m}$ & $\$ 810.4 \mathrm{~m}$ & $\$ 3507.7 \mathrm{~m}$ \\
Median & $\$ 33.1 \mathrm{~m}$ & $\$ 59.2 \mathrm{~m}$ & $\$ 209.9 \mathrm{~m}$ & $\$ 440.8 \mathrm{~m}$ \\
Std Dev & 1279.2 & 1061.3 & 1591.2 & 9057.5 \\
\hline
\end{tabular}

Table 3

Number of days the firms traded in the 91 day window

\begin{tabular}{cccc}
\hline & Exploration Sample & Resource Sample & Reserve Sample \\
\hline Observations & 1285 & 630 & 90 \\
Min & 3 & 5 & 1 \\
Max & 91 & 91 & 91 \\
Average & 63.8 & 66.6 & 67.9 \\
Median & 67.0 & 69.0 & 73.0 \\
Std Dev & 16.5 & 16.5 & 21.6 \\
\hline
\end{tabular}




\subsection{Mineral Resource Announcements}

The JORC code defines Mineral Resources "as a concentration or occurrence of a mineral of intrinsic economic interest in or on the Earth's crust in such form, quality and quantity that there are reasonable prospects for eventual economic extraction. The location, quantity, grade, geological characteristics and continuity of a Mineral Resource are known, estimated or interpreted from specific geological evidence and knowledge” (JORC, 2004 p. 10). As such, the reporting of a Mineral Resource will be made after sufficient exploration has been carried out in order to provide geological confidence to report a Mineral Resource.

In the sample period, 630 Mineral Resource announcements were made by 313 unique firms. Similarly to the exploration sample, Table 1 shows that the frequency of resource announcements increased during the sample period when commodity prices were increasing.

As a Mineral Resource announcement is made at a later stage in the life cycle of the mining firm than an Exploration announcement, firms issuing resource announcements are likely to be larger. This is confirmed by the information contained in Table 2 shows companies making Mineral Resource announcements have a median market capitalisation almost twice that of companies making Exploration announcements. Table 3 indicates that the frequency of trading was about the same for Exploration and Mineral Resource announcements.

\subsection{Ore Reserves Announcements}

An Ore Reserve "is the economically minable part of a Measured and/or Indicated Mineral Resource” (JORC, 2004 p. 14). To classify an Ore Reserve, appropriate assessments and studies must have been carried out, including considerations of mining, metallurgical, economic, marketing, legal, environmental and government factors. These assessments demonstrate at the time of reporting that extraction could reasonably be justified. A Mineral Resource can be converted into an Ore Reserve, after the application of all mining factors that may impact on the extraction of the ore.

As such Ore Reserve announcements are only made after Resource announcements have been made, and significantly more research and exploration has been conducted. Ore Reserve announcements are made much more sparingly as they are indicative that the company has mining production in mind. As a consequence, there were only 90 Reserve announcements made during the sample period by 67 unique firms. As these announcements are made much later in the mining life cycle, Table 2 shows that reserve announcing firms are on average almost four times larger than resource announcing firms, six times larger than exploration announcing firms. Table 3 shows that reserve announcing companies' trade slightly more frequently than companies making exploration or resource announcements.

\subsection{Other Data}

With the announcement samples created, the next step was to collect the data required to conduct the event studies. The source of this data was DataStream from which we obtained daily returns, market capitalisation and Level 6 Industry Classification Benchmarks (ICB) for all ASX listed mining companies over the sample period from 2004 to 2008 which are required given the need to choose matched firms. The ICB is a companyclassification system for stocks by industries which was developed by Dow Jones and FTSE (ICM, 2009). In total our sample companies are spread over 11 different mining companies with the largest being General Mining, Gold Mining, Nonferrous metals and Iron classifications. This code is used as the basis for matching companies which is an important part of our event study methodology as explained in a subsequent sub-section. 


\subsection{Event Study Methodology}

An event study methodology has been used to determine the stock price reaction over a period of time straddling the JORC compliant announcements. The time period over which we report in this paper is from 30 days before the announcement to 60 days after the announcement ${ }^{5}$. This total period was broken into a pre-announcement period (- 30 to -2 days), an announcement period ( -1 to +1 days) and a post-announcement period ( +2 to +60 days).

Many common criticisms are found in using event study methodology including the use of hindsight information, the incorrect specification of the market model (Bernard and Thomas 1990) and non-synchronous trading (Brown and Warner 1985). We attempt in our methodology outlined below to eliminate or minimise the impact the aforementioned problems

\subsection{Non-Synchronous Trading}

Czernkowski and Ferguson (2006) state share trading in the mining industry is characterised by low levels and is highly asynchronous, or "lumpy" in that a given stock may not trade for a number of days, even though average levels of trading in the market or even the industry are non-zero. Table 3 backs up these claims and shows that on average, exploration, resource and reserve announcing firms are only trading on around $70 \%$ of the days during the event window.

Non-synchronous trading has been shown to cause a number of problems in event studies (Leemakdej, 2009). In particular, it introduces biases in the calculation of the abnormal returns associated with (i) the preponderance of zero returns assigned to stocks on non-trading days and (ii) biases that this introduces into the estimation of the expected return model (e.g. market model) used to calculate the abnormal returns. In this study we attempt to deal with these problems in the following three ways:

1. We exclude stocks from our sample which trade on less than 18 days of the 91 day window that we sue in the event study (i.e. they must trade on average at least once a week).

2. We use three methods suggested by Kallunki (1997) for dealing with the non-trading when calculating the daily returns ${ }^{6}$ :

a. Use the bid price at the end of each trading day rather than the last traded price to calculate the returns each day

b. Assign a zero return to a stock on any day that it does not trade

c. Use a uniform return procedure in that after a day(s) of non-trading, the return on the next day of trading is apportioned back over the non-trading day(s) (e.g. assume that there is no trading for two days and then the return on the third day is $1.5 \%$, then a return of $0.5 \%$ is allocated to each of the three days)

3. We avoid the need to estimate an expected return model using a matched firm approach to estimate the abnormal returns (see next subsection)

\footnotetext{
${ }^{5}$ We also investigated other periods which did not provide any insights different to those reported in this paper.

${ }^{6}$ As the outcomes from using each of these three methods are almost identical, we only report the results obtained from using method (iii).
} 


\subsection{Event Study Using a Matched Firm Approach}

Barber and Lyon (1997) developed a methodology for conducting event studies, based on matching each firm subject to an event (e.g. making an exploration announcement) with a similar firm not subject to the event. Particularly due to the thin trading of many of the stocks included in our sample and the possibility of falling into the common trap of having a poor market model to use to calculate the abnormal (excess) returns, it was decided to use a matched firm approach in this study.

The abnormal (excess) return $\left(\mathrm{ar}_{\mathrm{it}}\right)$ for "event" stock i on event date $\mathrm{t}$ is then calculating each day by subtracting the return on that day for the matched firm $\left(\mathrm{r}_{\mathrm{mt}}\right)$ from the return of the "event" firm $\left(\mathrm{r}_{\mathrm{it}}\right)$ :

$$
\mathrm{ar}_{\mathrm{it}}=\mathrm{r}_{\mathrm{it}}-\mathrm{r}_{\mathrm{mt}}
$$

The average abnormal return (ARR) on a portfolio of $n$ stocks for event day $t$ is the equally weighted average of the abnormal returns:

$$
\mathrm{ARR}_{\mathrm{t}}=\frac{1}{n} \sum_{t=1}^{n} \omega_{\text {it }}^{n}
$$

The cumulative adjusted aftermarket performance from event day q to event day s is the summation of the average adjusted returns:

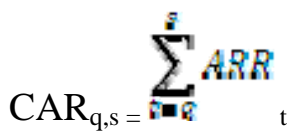

To test for the statistical significance of these cumulative average abnormal returns T-Statistics are calculated. The t-statistic for the average abnormal return is computed for each day as

$$
\text { AAR T-Statistic }=\mathrm{AAR}_{\mathrm{t}} * \sqrt{N_{\mathrm{t}}} / \mathrm{SD}_{\mathrm{t}}
$$

where $\mathrm{AAR}_{\mathrm{t}}$ is the average index adjusted return for day t, $N_{t}$ is the number of observations on day t, and $S D_{t}$ is the cross-sectional standard deviation of the adjusted returns for day $t$.

Following the method used in Ritter (1991) the t-statistic for the cumulative average abnormal return on day $t, \mathrm{CAR}_{\mathrm{q}, \mathrm{s}}$ is computed as

$$
\text { CAR T-Stat }=\text { CAR }_{\mathrm{q}, \mathrm{s}} * \sqrt{N}_{\mathrm{t}} / \operatorname{csd}_{\mathrm{t}}
$$

where $N_{t}$ is the number of observations, and $\operatorname{csd}_{\mathrm{t}}$ is computed as

$$
\operatorname{csd}_{t}=[\mathrm{q}-\mathrm{s} * \operatorname{var}+2 *((\mathrm{q}-\mathrm{s})-1) \cdot \operatorname{cov}]^{\wedge} 1 / 2
$$

where q-s represents the amount of days between event day q and event day s.

var is the average cross-sectional variance over q-s days.

$c o v$ is the first-order auto covariance of the $\mathrm{AR}_{\mathrm{t}}$ series.

In finding a matched firm for our sample firms, it was decided that matching on industry would be a crucial factor as Tufano (1998) has found a strong correlation between resource company stock returns and underlying commodity prices, thus it was decided the main criteria for matching firms was that they were in the same industry, specifically the same level 6 industry classification benchmark (ICB) group. As the ICB segregates firms based upon the general commodity in which they deal, the first step in the process was to match the sample firm with other forms with the same level 6 ICB. The actual matched firm chosen was then the one with closest in terms of size that traded for a minimum of 18 days over the event period. 


\section{Section 5: Results}

\subsection{Exploration Results}

As we noted earlier the announcement of exploration results are made early in the cycle at a time when it is unlikely to be possible to estimate the economic value of what has been identified. Such information is undoubtedly positive in terms of its implications for extending the proven reserves of the company. However, it is not possible to identify how the announcement rates relative to the market's expectations and so it is not possible to hypothesise as the nature of the markets reaction to the announcement. Indeed, the main focus of this paper is on providing evidence as to how the market does react around the time of such announcements which may not only provide useful insights but also generate future research.

Figure 4

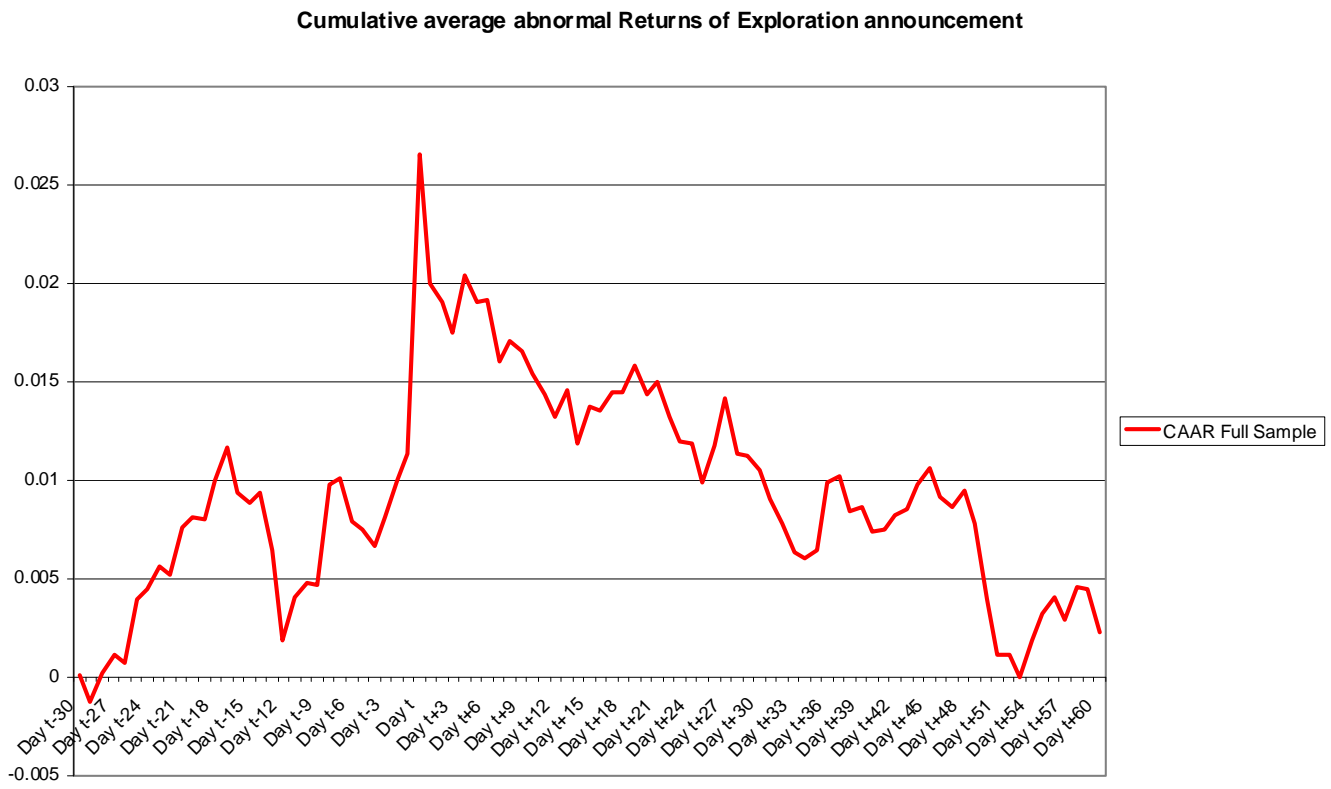

\begin{tabular}{ccc}
\hline & \multicolumn{2}{c}{ Full Sample (1238) } \\
\hline Event Window & CAR & T-Stat \\
$\mathbf{- 3 0 / 6 0}$ & $0.22 \%$ & 0.18 \\
$-\mathbf{3 0} / \mathbf{- 2}$ & $0.99 \%$ & 1.36 \\
$\mathbf{- 1}$ / $\mathbf{1}$ & $1.00 \% * * *$ & 4.10 \\
$\mathbf{0}$ & $1.52 \% * * *$ & 9.25 \\
$\mathbf{0}$ / 1 & $0.86 \% * *$ & 4.22 \\
$\mathbf{2}$ / $\mathbf{6 0}$ & $-1.77 \%^{*}$ & -1.71 \\
\hline
\end{tabular}

We report in Figure 4 and the associated table, the cumulative abnormal returns (CAR) over the period from 30 day before the announcement of explorations results to 60 days post announcement for 1,184 announcements made over our sample period. The evidence is quite conclusive that the release of the information does have a significant positive impact on the company's share price (relative to similar companies that do not make an announcement) during the three day announcement window but particularly on the day that the announcement was posted on the ASX website. It would appear that there has been some anticipation by the market of the announcement especially during the two-week period just prior to the announcements when the "announcement" firms outperformed by about $0.75 \%$. Finally, there was almost an immediate correction after the announcement with the "announcement" firms consistently under-performing for several weeks. In 
summary, there is evidence to support some anticipation within the market of the announcement and quite a large upward adjustment in price at the time of its release but the subsequent downward movement suggests that on reflection investors found the announcement to be a disappointment.

We have previously noted significant variability within our sample in a number of dimensions, but especially size and frequency of trading. It may well be that we obtain different perspectives on the market reaction to exploration results if we divide the sample in accordance with a number of company characteristics. The ones that we choose are:

(i) company size as measured by the value of the company's equity where we split the sample up into (relatively) large companies (i.e. those in the top tercile) and small companies,

(ii) the number of days that the company's shares trade over the event window where we separated the sample up into (relatively) high trading frequency (those in the top tercile) and low trading frequency, and

(iii) whether at the time of the announcement the company is earning any revenue Insights into the characteristics of each of the sub-samples formed can be seen in Table 4.

Table 4

Table showing the median of samples split by various characteristics

\begin{tabular}{|l|c|c|}
\hline \multicolumn{3}{|c|}{ Exploration Sample } \\
\hline \multirow{2}{*}{ SIZE (in \$Million) } & Small & Large \\
\cline { 2 - 3 } & $\$ 18.9 \mathrm{~m}$ & $\$ 177.6 \mathrm{~m}$ \\
\cline { 2 - 3 } Trading (\% of Days Traded) & Low Trading & High Trading \\
\cline { 2 - 3 } & $65.93 \%$ & $86.81 \%$ \\
\hline \multirow{2}{*}{ \% of sample with Operating Revenue } & \multicolumn{2}{|c|}{$54.10 \%$} \\
\hline
\end{tabular}

\subsubsection{Exploration Results and Company Size}

The difference between the size of the small and large companies making exploration announcements is apparent from Table 4 with the median large company being almost tentimes the size of the median small company. The CAARs of the small and large companies making exploration announcements are reported in Figure 5 and the associated table. 
Exploration by Size Terciles

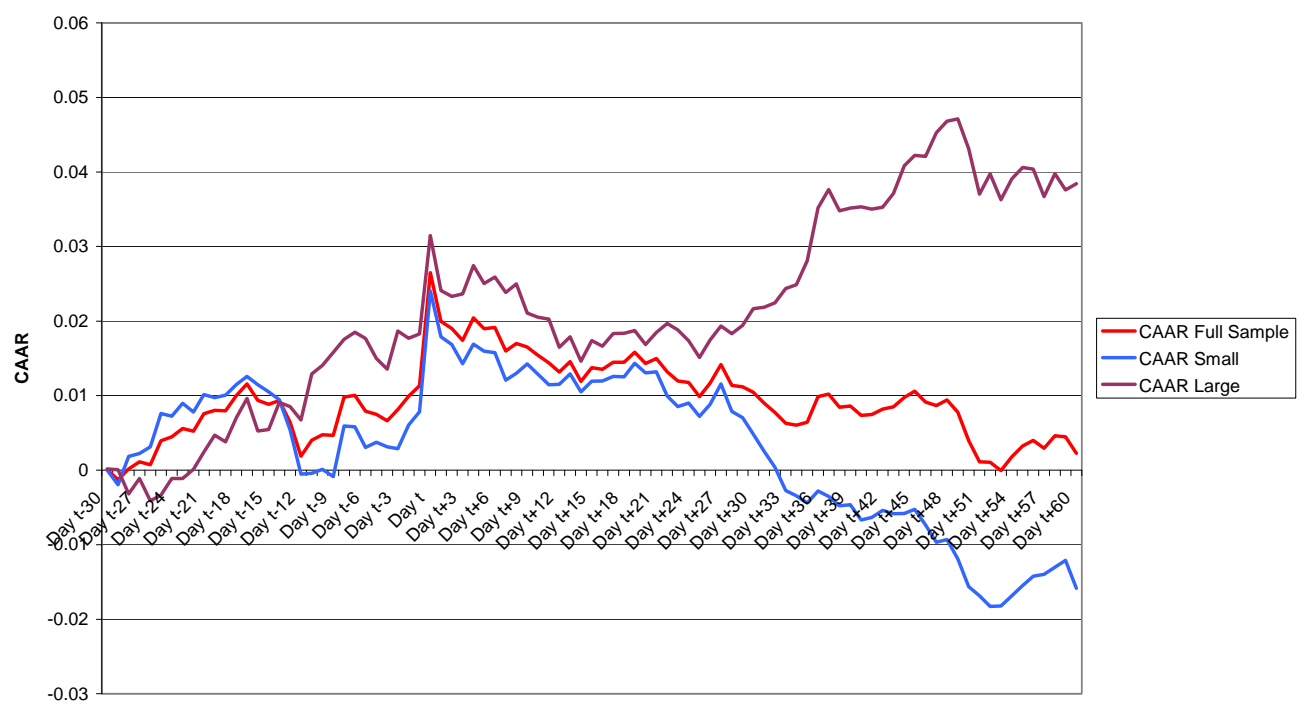

\begin{tabular}{|c|c|c|c|c|c|c|}
\hline & \multicolumn{2}{|c|}{ Full Sample (1238) } & \multicolumn{2}{|c|}{ Small Sample (825) } & \multicolumn{2}{|c|}{ Large (413) } \\
\hline Event Window & CAR & T-Stat & CAR & T-Stat & CAR & T-Stat \\
\hline$-30 / 60$ & $0.22 \%$ & 0.18 & $-1.59 \%$ & -0.98 & $3.84 \% *$ & 1.86 \\
\hline$-30 /-2$ & $0.99 \%$ & 1.36 & $0.60 \%$ & 0.66 & $1.77 \%$ & 1.51 \\
\hline$-1 / 1$ & $1.00 \% * * *$ & 4.10 & $1.18 \% * * *$ & 3.79 & $0.64 \%$ & 1.66 \\
\hline O & $1.52 \% * * *$ & 9.25 & $1.62 \% * * *$ & 7.62 & $1.32 \% * * *$ & 5.29 \\
\hline $\mathbf{0} / 1$ & $0.86 \%$ & 4.22 & $1.00 \% * * *$ & 3.83 & $0.58 \% *$ & 1.82 \\
\hline $2 / 60$ & $-1.77 \% *$ & -1.71 & $-3.37 \% * * *$ & -2.58 & $1.43 \%$ & 0.86 \\
\hline
\end{tabular}

We found that separating the sample by size does provide us with some insights than when we just examined the whole sample. There are some similarities in the behaviour of the small and large samples up to and including the announcement date. However, in the case of the small companies this is far from being statistically significant and it is much stronger for large companies. For both groups there is a large upward adjustment in price at the time of the announcement highlighting the significant importance that the market attributes to this information. However, the large difference between the behaviour of the two subsamples occurs after the announcement where there is an immediate and continuing decline in the price of small companies after the announcement which is not the case at all for the larger companies. It seems for small firms about which there will be less in the way of available information that the initial reaction to an exploration announcement is very positive but the initial euphoria quickly turns to disappointment. In contrast with the larger companies about which more is known, the market to some extent anticipates the information, responds very positively when it is actually released moving the price to a level which is at least maintained in the post-announcement period. It is significant that over the whole event window, the larger companies generate positive cumulative abnormal return whereas these are negative for the smaller companies.

\subsubsection{Exploration Results and Frequency of Trading}

As can be seen from Table 4, the median low frequency trading companies in our sample trade on about two out of every three days, while this is almost seven out of every eight days for the median higher frequency trading companies. The results from the event study conducted on these two sub-samples are reported in Figure 6 and the associated table.

\section{Figure 6}




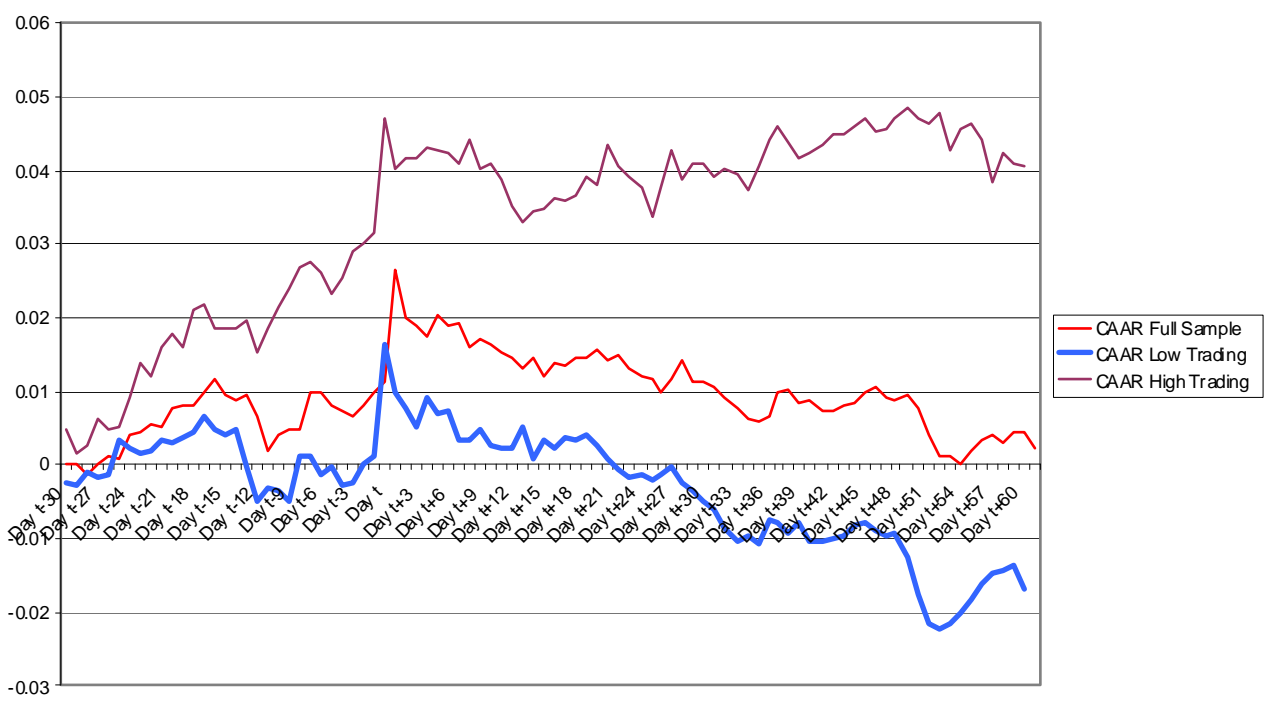

\begin{tabular}{|c|c|c|c|c|c|c|}
\hline & \multicolumn{2}{|c|}{ Full Sample (1238) } & \multicolumn{2}{|c|}{ Low Trading (825) } & \multicolumn{2}{|c|}{ High Trading (413) } \\
\hline Event Window & CAR & T-Stat & CAR & T-Stat & CAR & T-Stat \\
\hline$-30 / 60$ & $0.22 \%$ & 0.18 & $-1.69 \%$ & -1.05 & $4.05 \% *$ & 1.89 \\
\hline$-30 /-2$ & $0.99 \%$ & 1.36 & $-0.01 \%$ & -0.01 & $2.99 \% * *$ & 2.47 \\
\hline$-1 / 1$ & $1.00 \% * * *$ & 4.10 & $0.98 \% * * *$ & 3.20 & $1.04 \% * *$ & 2.60 \\
\hline $\mathbf{0}$ & $1.52 \% * * *$ & 9.25 & $1.51 \% * * *$ & 7.32 & $1.53 \% * * *$ & 5.71 \\
\hline $\mathbf{0} / \mathbf{1}$ & $0.86 \% * * *$ & 4.22 & $0.86 \% * * *$ & 3.33 & $0.87 \% * * *$ & 2.63 \\
\hline $2 / 60$ & $-1.77 \% *$ & -1.71 & $-2.67 \% * *$ & -2.07 & $0.02 \%$ & 0.01 \\
\hline
\end{tabular}

In this case we obtain very clear separation between the two sub-samples. In the case of the companies that trade most, the anticipation of the announcement commences almost 30 days in advance with a further significant increase in price at the time of the announcement relatively flat performance thereafter. For the sample companies that trade less frequently, the performance up to the announcement period is flat then there are quite large positive abnormal returns centred on the release There may be some self-selection in drawing up these sub-samples as the relatively poor performance of the less frequently traded stocks over the event period may be an important factor in contributing to their infrequent trading. In contrast the more frequently traded stocks that make exploration announcements realise significant positive abnormal returns over the event window.

\subsubsection{Exploration Results and Revenue}

Almost half of the companies releasing exploration results (45.9\%) have no revenue at the time of their announcements and so could be considered pure exploration companies. One possibility to be considered is whether exploration announcements have a different market impact for these companies than it does for companies that already have a revenue source. We report our findings in Figure 7 and the associated table. 
Table 7

Exploration Sample Split by Opreating Revenue

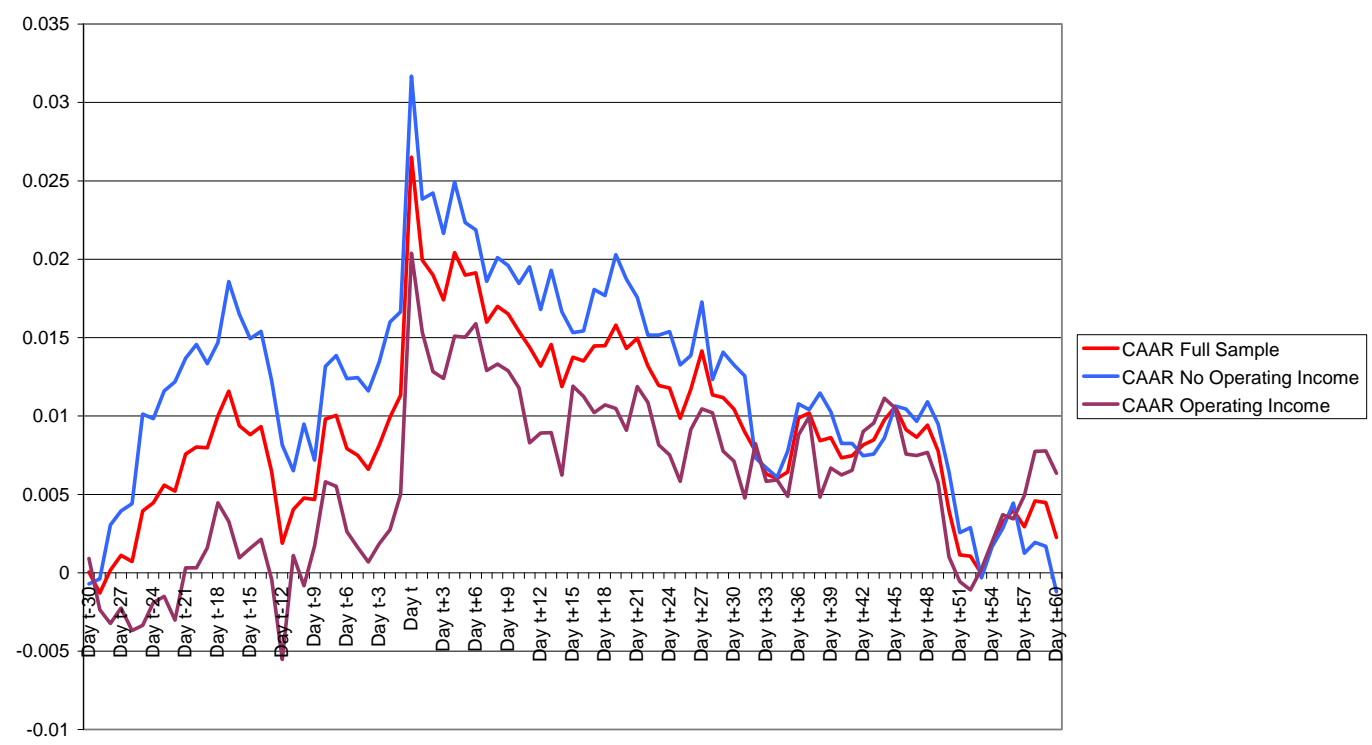

Full Sample

(1238)
No Operating Revenue

(671)

\begin{tabular}{|c|c|c|c|c|c|c|}
\hline $\begin{array}{l}\text { Event } \\
\text { Window }\end{array}$ & CAR & T-Stat & CAR & T-Stat & CAR & T-Stat \\
\hline$-30 / 60$ & $0.22 \%$ & 0.18 & $-0.12 \%$ & -0.07 & $0.63 \%$ & 0.34 \\
\hline$-30 /-2$ & $0.99 \%$ & 1.36 & $1.60 \%$ & 1.60 & $0.27 \%$ & 0.26 \\
\hline$-1 / 1$ & $1.00 \% * * *$ & 4.10 & $0.78 \% * *$ & 2.32 & $1.26 \% * * *$ & 3.55 \\
\hline 0 & $1.52 \% * * *$ & 9.25 & $1.50 \% * * *$ & 6.48 & $1.54 \% * * *$ & 6.66 \\
\hline 0 / 1 & $0.86 \% * * *$ & 4.22 & $0.72 \% * *$ & 2.55 & $1.03 \% * * *$ & 3.49 \\
\hline $2 / 60$ & $-1.77 \% *$ & -1.71 & $-2.51 \% *$ & -1.76 & $-0.90 \%$ & -0.60 \\
\hline
\end{tabular}

In this case we get very little difference between the two sub-samples: both outperform to a limited extent before the information release, increase in price by about the same amount at the time of the announcement and then underperform in the post-announcement period. The only difference being that non-revenue earning sub-sample does slightly better in the period running up to the announcement and a bit worse in the period subsequent to the announcement.

\subsection{Mineral Resources Announcements}

Mineral Resource announcements are made at a time when sufficient exploration has been undertaken to be confident that commercially viable prospect has been identified. Such an announcement is undoubtedly positive in terms that it suggests that this prospect will make a positive contribution to the company's value. Of course, again we do not know whether the announcement provided any new information and how it compared to the market's expectations. The markets response to such announcements is presented in Figure 8 and the associated table. 
Figure 8

Cumulative average abnormal returns of Resource announcements

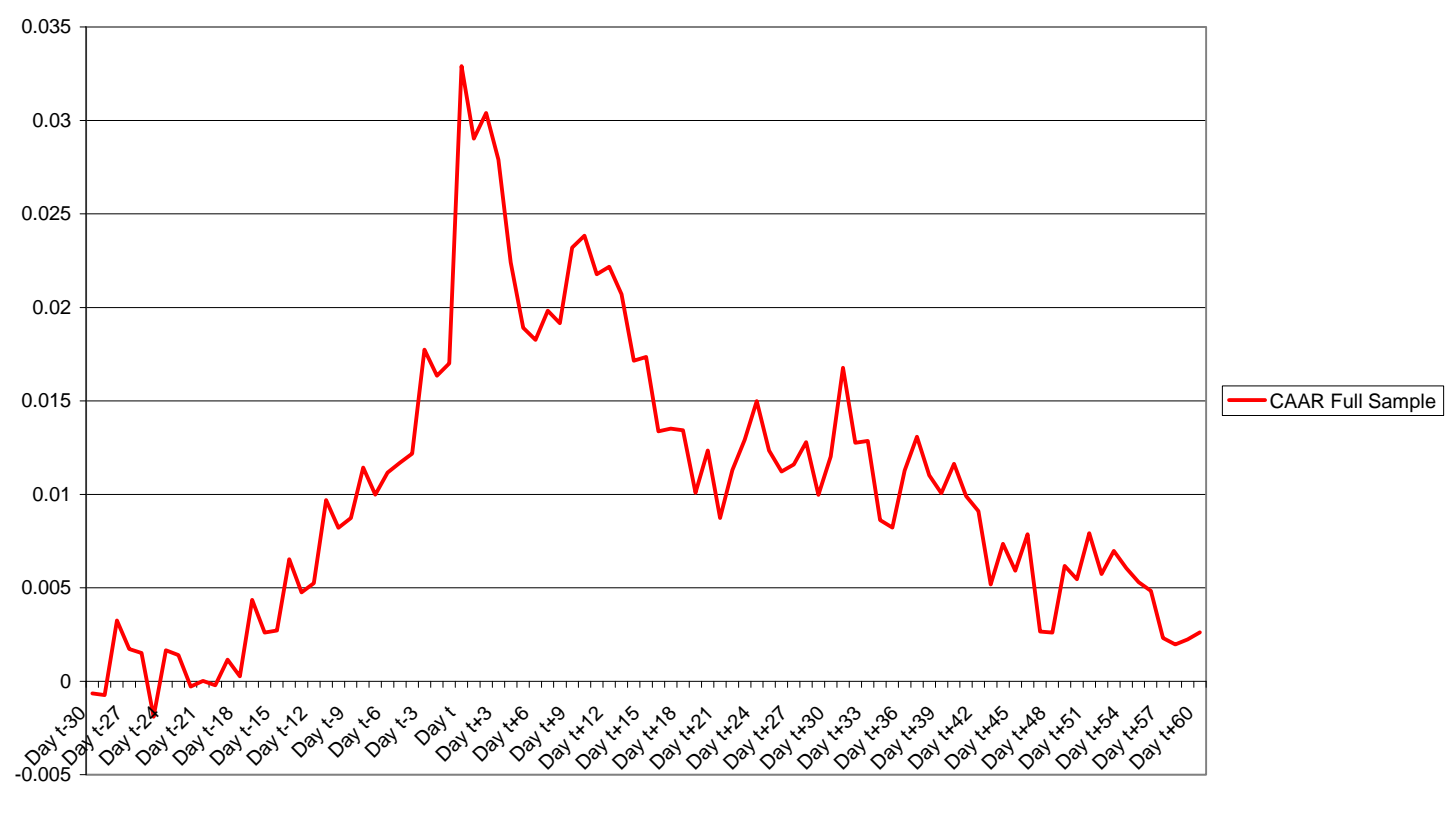

Full Sample (616)

\begin{tabular}{crr}
\hline Event Window & \multicolumn{1}{c}{ CAR } & \multicolumn{1}{c}{ T-Stat } \\
$\mathbf{- 3 0 / 6 0}$ & $0.26 \%$ & 0.15 \\
$\mathbf{- 3 0} / \mathbf{- 2}$ & $1.63 \% *$ & 1.65 \\
$\mathbf{- 1} / \mathbf{1}$ & $1.27 \% \%^{* *}$ & 3.81 \\
$\mathbf{0}$ & $1.59 \% \%^{* *}$ & 6.74 \\
$\mathbf{0} / \mathbf{1}$ & $1.20 \%{ }^{* *}$ & 4.32 \\
$\mathbf{2}$ / $\mathbf{6 0}$ & $-2.64 \% *$ & -1.87 \\
\hline
\end{tabular}

The results are not dissimilar but stronger than those that we found for the exploration announcements. The price adjustment to the resource announcement would seem to commence about three weeks before the release with abnormally returns accumulating to something like $1.5 \%$ during this period. Then we have a large and positive abnormal return of a similar amount on the announcement day suggesting that about half of the information contact has been anticipated. Finally, there is an almost immediate downward adjustment which continues over the reminder of the event window and results in a negative accumulated abnormal return that completely offsets that gained in the period up to and including the announcement. This is another instance of the market interpreting the announcement as good news and then immediately reassessing and marking down the price of the stock over an extended period.

Again in order to see if we can obtain some interesting insights, we divide the total sample on the basis of (i) size, (ii) trading frequency and (iii) whether the company is earning any revenue. The characteristics of the sub-samples are reported in Table 5. 
Table 5

Table showing the median of samples split by various characteristics Resource Sample

SIZE (in \$Million)

Trading (\% of Days Traded)

$\%$ of sample with Operating Income

\begin{tabular}{|c|c|}
\hline Small & Large \\
\hline$\$ 29.1 \mathrm{~m}$ & $\$ 477.6 \mathrm{~m}$ \\
\hline \multicolumn{2}{|c|}{} \\
\hline Low Trading & High Trading \\
\hline $68.13 \%$ & $91.21 \%$ \\
\hline \multicolumn{2}{|c|}{$56.10 \%$} \\
\hline
\end{tabular}

\subsubsection{Mineral Resource Announcements by Size}

We have already seen that the size of companies making resource announcements is larger than that of those making exploration announcements (see table 2). We now see that we divide our sample up into large and small we get a larger differentiation with the median large companies making resiource announcements being 15 times the size of the median small company. We provide in Figure 9 and the associated table the results of the event study that we conducted on the small and large companies making resource announcements.

Figure 9

Resource Sample By Size

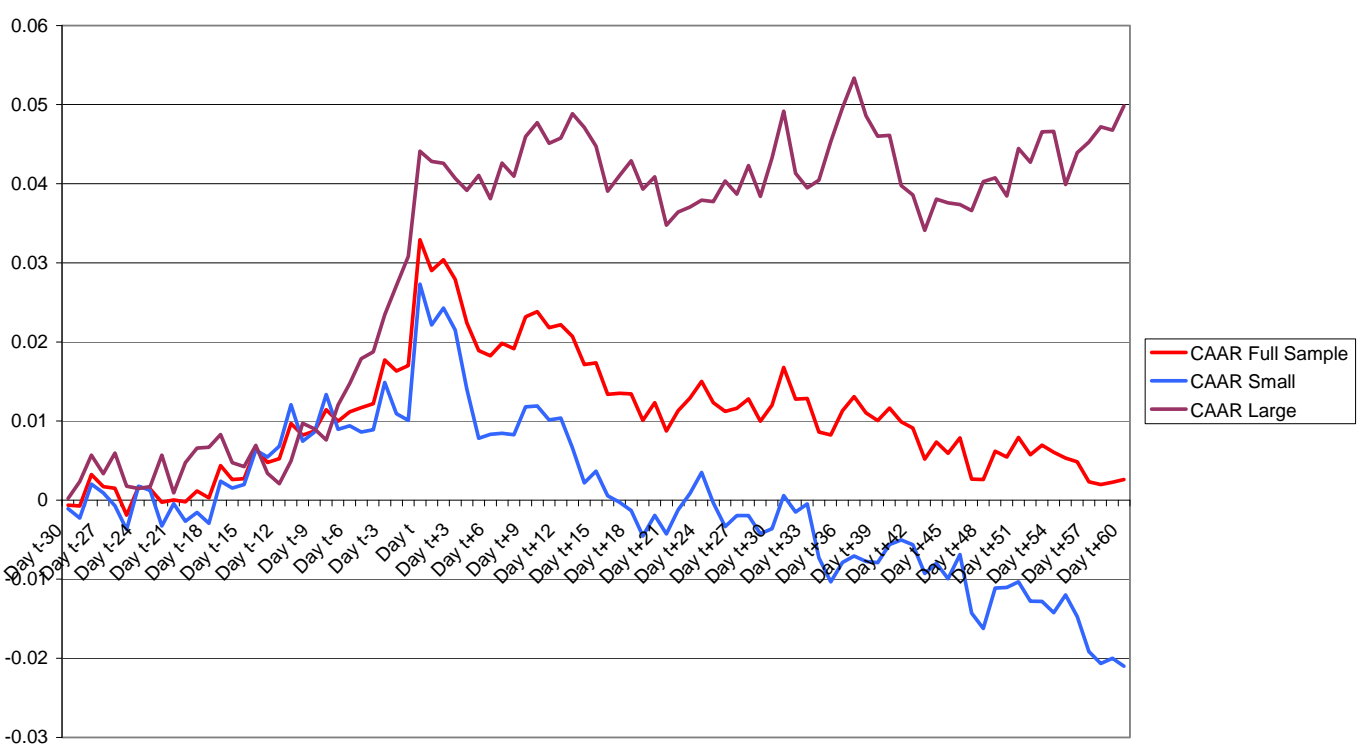

\begin{tabular}{|c|c|c|c|c|c|c|}
\hline & \multicolumn{2}{|c|}{ Full Sample (616) } & \multicolumn{2}{|c|}{ Small Sample (410) } & \multicolumn{2}{|c|}{ Large (205) } \\
\hline Event Window & CAR & T-Stat & CAR & T-Stat & $\overline{C A R}$ & T-Stat \\
\hline$-30 / 60$ & $0.26 \%$ & 0.15 & $-2.10 \%$ & -0.94 & $4.98 \% *$ & 1.79 \\
\hline$-30 /-2$ & $1.63 \% *$ & 1.65 & $1.09 \%$ & 0.87 & $2.71 \% *$ & 1.72 \\
\hline$-1 / 1$ & $1.27 \% * * *$ & 3.81 & $1.12 \% * *$ & 2.61 & $1.57 \% * * *$ & 3.05 \\
\hline $\mathbf{0}$ & $1.59 \% * * *$ & 6.74 & $1.72 \% * * *$ & 5.55 & $1.33 \% * * *$ & 3.90 \\
\hline $\mathbf{0} / \mathbf{1}$ & $1.20 \% * * *$ & 4.32 & $1.21 \%$ & 3.35 & $1.20 \% * * *$ & 2.83 \\
\hline $2 / 60$ & $-2.64 \% *$ & -1.87 & $-4.31 \% * *$ & -2.40 & $0.70 \%$ & 0.31 \\
\hline
\end{tabular}

We see here what is becoming a familiar story with the small and large "resource" companies behaving somewhat similarly up to and including the period of the 
announcement but then the larger companies holding on to their gains while those of the small companies completely fall away. Overall the larger companies have a stronger run up and a greater positive reaction at the time of the announcement, thus accumulating abnormal returns in excess of $4 \%$ which are held on to over the post-announcement period. In contrast the smaller companies accumulate abnormal returns of around $2.5 \%$ as at the time of the announcement but then proceed to give back over $4 \%$ over the postannouncement period.

\subsubsection{Mineral Resource Announcements by Trading Frequency}

Consistent with companies making mineral resource announcements being further into their life cycle than those making exploration announcements, we see that mineral announcement companies trade more frequently than exploration announcement companies. Still there is a fair degree of variability within this group and so our medial low frequency trading sub-sample company trades about two in every three days whereas the median high frequency company trades about ten in every 11 days. The results of the event study that are conducted on our high and low frequency sub-samples of mineral resource announcement companies is reported in Figure 10 and the associated table.

Unlike the finding for the exploration announcements, there is little in the way of difference between the behaviour of the low and high frequency sub-sample over the event window. In both sub-samples there is a steady run up in abnormal returns in the period prior to the announcement, a significant upward movement in price at the time of the announcement, all followed by a correction in the post-announcement period. The major difference between the two sub-samples being that market reaction to the announcement is larger for the low frequency trading sub-sample but their post-announcement downward adjustment is both more immediate and larger.

Figure 10

Resource sample split by Trading Level

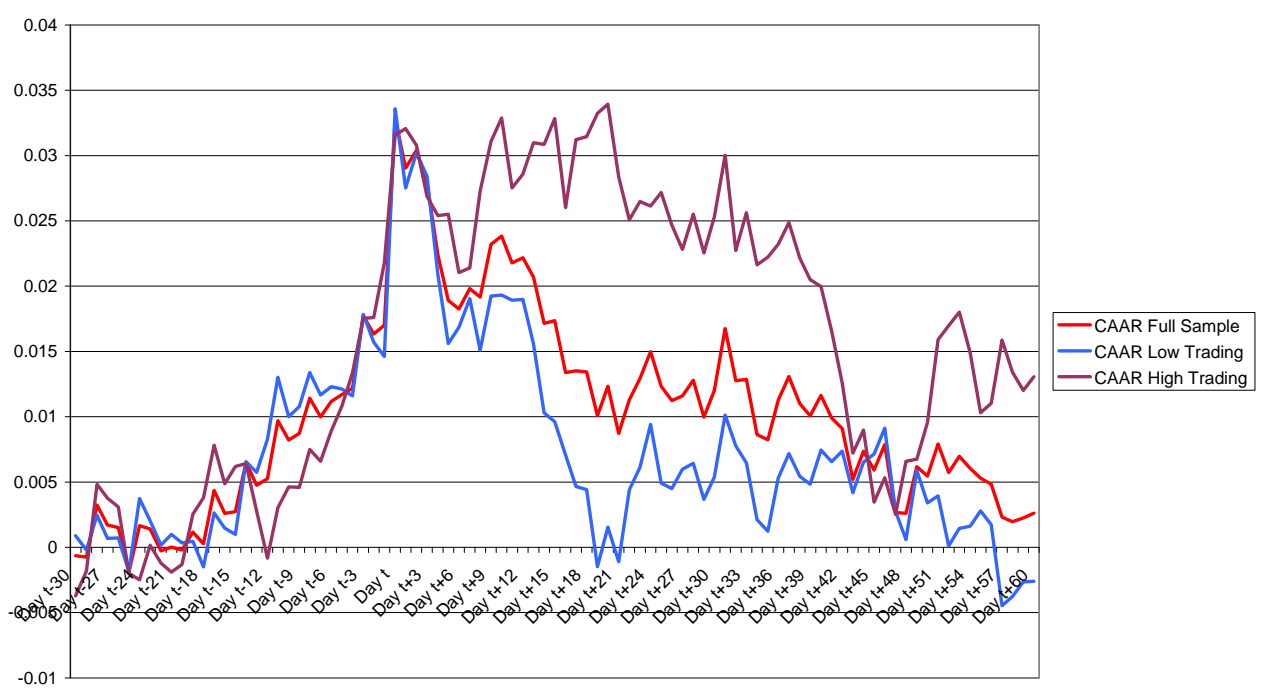




\begin{tabular}{crrrrrrr}
\hline & \multicolumn{2}{c}{ Full Sample (615) } & \multicolumn{2}{c}{$\begin{array}{c}\text { Low Trading } \\
\mathbf{( 4 1 0 )}\end{array}$} & \multicolumn{2}{c}{$\begin{array}{c}\text { High Trading } \\
(\mathbf{2 0 5})\end{array}$} \\
\hline Event Window & \multicolumn{1}{c}{ CAR } & T-Stat & \multicolumn{1}{c}{ CAR } & T-Stat & CAR & T-Stat \\
$\mathbf{- 3 0 / 6 0}$ & $0.26 \%$ & 0.15 & $-0.26 \%$ & -0.12 & $1.31 \%$ & 0.45 \\
$-\mathbf{- 3 0} / \mathbf{- 2}$ & $1.63 \% *$ & 1.65 & $1.57 \%$ & 1.27 & $1.76 \%$ & 1.06 \\
$\mathbf{- 1} / \mathbf{1}$ & $1.27 \% * * *$ & 3.81 & $1.18 \% * * *$ & 2.81 & $1.45 \% * * *$ & 2.66 \\
$\mathbf{0}$ & $1.59 \% * * *$ & 6.74 & $1.90 \% * * *$ & 6.44 & $0.98 \% * *$ & 2.51 \\
$\mathbf{0} / \mathbf{1}$ & $1.20 \% * * *$ & 4.32 & $1.29 \% * * *$ & 3.67 & $1.03 \% * *$ & 2.29 \\
$\mathbf{2}$ / $\mathbf{6 0}$ & $-2.64 \% *$ & -1.87 & $-3.01 \% *$ & -1.71 & $-1.90 \%$ & -0.81 \\
\hline
\end{tabular}

\subsubsection{Resource Announcements by Revenue}

As with exploration announcement, almost half of the firms making mineral resource announcements do not have any revenues suggesting that the prospect to which the announcement relates may prove to be the first that generates revenue. Our findings for these sub-samples are reported in Figure 11 and the associated table.

Figure 11

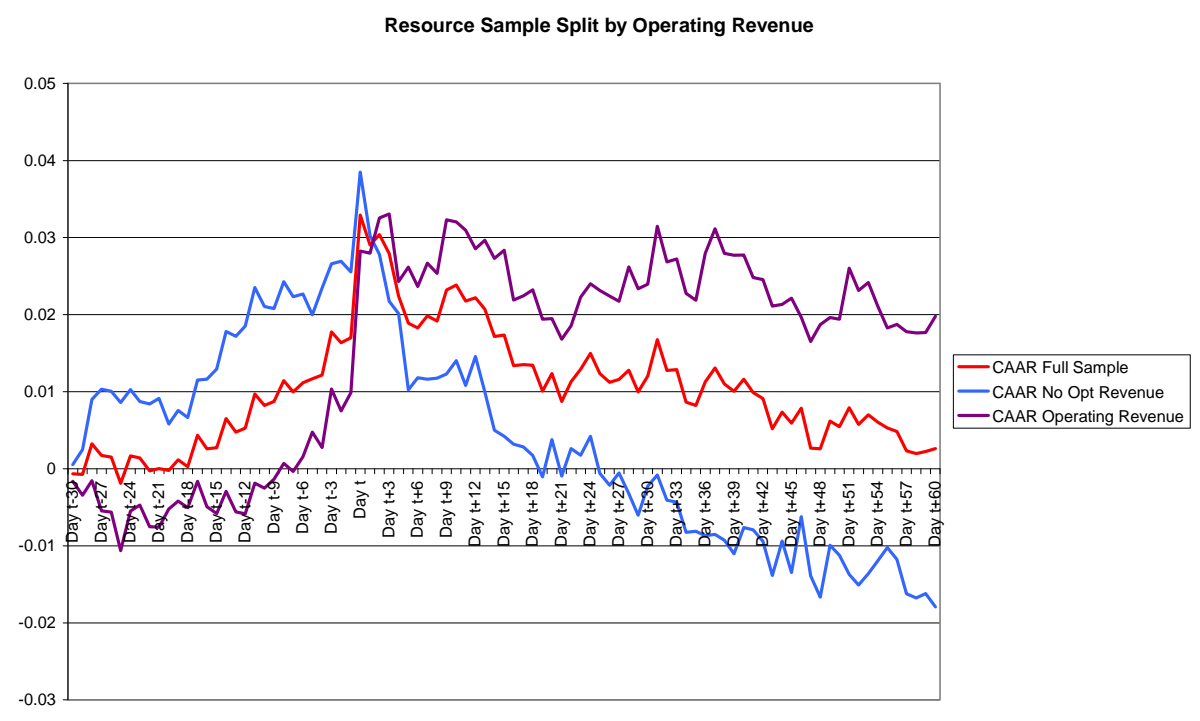

\begin{tabular}{|c|c|c|c|c|c|c|}
\hline & \multicolumn{2}{|c|}{ Full Sample (615) } & \multicolumn{2}{|c|}{ No Operating Revenue (280) } & \multicolumn{2}{|c|}{ Operating Revenue (345) } \\
\hline $\begin{array}{l}\text { Event } \\
\text { Window }\end{array}$ & CAR & T-Stat & CAR & T-Stat & CAR & T-Stat \\
\hline$-30 / 60$ & $0.26 \%$ & 0.15 & $-1.79 \%$ & -0.68 & $1.98 \%$ & 0.84 \\
\hline$-30 /-2$ & $1.63 \% *$ & 1.65 & $2.69 \% *$ & 1.80 & $0.75 \%$ & 0.56 \\
\hline$-1 / 1$ & $1.27 \% * * *$ & 3.81 & $0.33 \%$ & 0.66 & $2.05 \% * * *$ & 4.61 \\
\hline $\mathbf{0}$ & $1.59 \% * * *$ & 6.74 & $1.29 \% * * *$ & 3.63 & $1.84 \% * * *$ & 5.85 \\
\hline $\mathbf{0} / \mathbf{1}$ & $1.20 \% * * *$ & 4.32 & $0.47 \%$ & 1.12 & $1.81 \% * * *$ & 4.90 \\
\hline $2 / 60$ & $-2.64 \% *$ & -1.87 & $-4.82 \% * *$ & -2.27 & $-0.82 \%$ & -0.43 \\
\hline
\end{tabular}

In this case there is a clear difference in the behaviour of the market of "revenue" and "non-revenue" companies around the time of a mineral resource announcement. It would appear that in the case of the non-revenue stocks, the market begins to anticipate the announcement well in advance of its release and about two-thirds of the information $n$ is in the price at the time of its release. Although there is also some anticipation on the case of the revenue sub-sample, it is much smaller and begins much closer to the announcement. The abnormal returns of the revenue sub-sample during the announcement period 
accumulate to about $2 \%$ suggesting that only two per cent of the information content of the announcement has been anticipated. The real difference between the two sub-samples occurs during the post-announcement period where the revenue sub-sample holds on to almost all of the gains made in the pre-announcement and announcement periods whereas the non-revenue sub-sample goes into an immediate decline which results in all of the positive abnormal returns accumulated up to, and including, the announcement and given back plus then some more.

\subsection{Ore Reserve Announcements}

Ore reserve announcements represent the end of the process basically when all of the work has been undertaken to proceed to extraction. The fact that we have only been able to identify 85 of such announcements over a four year period indicates just how rare they are in comparison resource announcements and especially exploration announcements. As we saw in table 2 and 3, the median company making a reserve announcement is much larger than the median firm making a resource announcement. This reflects the need for a company before commencing extraction to either have to raise a lot of capital or to be absorbed by a larger company. We report in Figure 12 and the associated table our results for the event study that we conducted on reserve announcements.

The results do provide some evidence of a run up prior to the release of the announcement and a fairly equal decline subsequent to the announcement. Although this result is similar to that found for both the exploration and resource announcements, in this case neither the run up nor the decline are significant. The most surprising result is that there is no market reaction to the release of the information which contrasts very much with the strong upward adjustment that we found for exploration and resource announcements.

We take our results to tell us either that the market is typically fully aware of the content of the reserve announcements prior their release or that our failure to identify any significant results is a consequence of the small sample size. We can certainly see good reason for why there may be no reaction at the time of the information release as this may have been preceded by the company seeking funding during which time much information might be disseminated. However, any further insights on this will have to wait for the analysis from a much larger sample.

Figure 12

Cumulative average abnormal returns of Reserve announcements

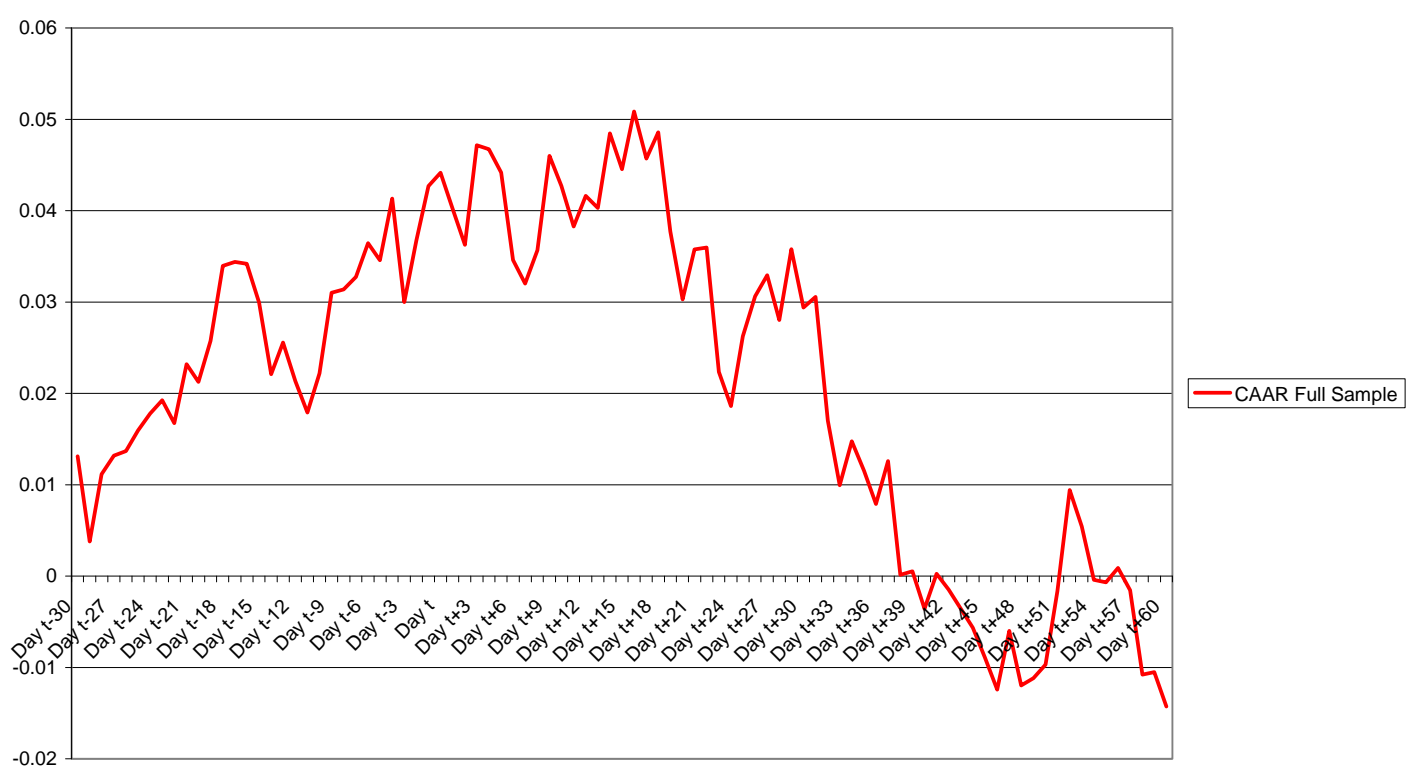




\begin{tabular}{ccc}
\hline & \multicolumn{2}{c}{ Full sample (85) } \\
\hline Event Window & CAR & T-Stat \\
$\mathbf{- 3 0 / 6 0}$ & $-1.43 \%$ & -0.31 \\
$-\mathbf{- 3 0} / \mathbf{- 2}$ & $3.67 \%$ & 1.39 \\
$\mathbf{- 1} / \mathbf{1}$ & $0.35 \%$ & 0.40 \\
$\mathbf{0}$ & $0.15 \%$ & 0.38 \\
$\mathbf{0} / \mathbf{1}$ & $-0.25 \%$ & -0.35 \\
$\mathbf{2}$ / 60 & $-5.45 \%$ & -1.45 \\
\hline
\end{tabular}

We did undertake the same analysis by sub-samples as was the case for the exploration and resource announcements (i.e. by size, trading frequency and revenue/non-revenue). We will not separately report these results here both because they did not provide a lot in the way of additional insights and, of course, as they suffered even more from the problem of small sample size. Most importantly, we can report that there was not a single sub-sample that experienced a significant price adjustment at the time of the information release. The next most interesting finding was that the smaller companies most infrequently traded and the companies yet to earn any revenue all generated significant positive abnormal returns in the prior to the information release. We believe that this is evidence both of information leakages as these companies seek to raise the necessary funds to go into production and that such an event is considered by the market to be more important for junior mining company than it is for a more established mining company. On the other hand it is the large, more frequently traded and revenue earnings companies who suffer the significant price declines after a reserve announcement which contrasts with our findings for both exploration and resource announcements where it was the less established mining companies who experience the greatest post-announcement declines.

\section{Section 6: Summary Conclusions}

We made the point earlier that there appears no way of determining in advance the markets expectations as to the information content of announcements by mining companies. Our expectations were that the market would respond in a positive way because we believe that the exploration, resource and reserve announcements by mining companies that we are examining are akin to good earnings announcements made by non-mining companies. Indeed our findings would seem to confirm the importance of these announcements as the market responds very positively to the release of both exploration and earnings announcements by mining companies. This being the case it was surprising to find absolutely no evidence that the market responds to reserve announcements. One interpretation of this finding is that reserve announcements contain no price sensitive information but this is unlikely given that they provide a clear indication that the company has a prospect that is worth putting into production. A second interpretation is that the lack of a market response is due to all of the information in the announcement being impounded in the price prior to its release. As we point out, and our findings support, this is more likely to be the case for junior mining companies as it is highly probably that they will have had to "disclose" this information in the process of attempting to raise capital to fund the next stage of extraction.

The evidence on the market reaction to earnings announcements suggests that there is some anticipation of the announcement, a substantial adjustment at the time of the release followed by an extended period of post-announcement drift. We certainly see the anticipation with respect to all three types of announcements by mining companies A comparison of the cumulative abnormal returns over the 30 days before the announcement with that on the announcement day suggests that bout $40 \%$ is anticipated with respect to exploration announcements, $50 \%$ with respect to resource announcements and almost 
$100 \%$ with respect to reserve announcements. Such a result must be a concern to regulators, especially when it is recognised that there should be much greater uncertainty with respect to the timing and content of these announcements by mining companies that there will be with respect to the timing and content of earnings numbers released by nonmining companies. One potential explanation that we see for this high level of anticipation of these announcements is the high number of informed parties outside the company. By this we mean the mining engineers, geologist and others who are contracted by the company and contribute to the establishment of the prospect. The wider the circle of informed people, the greater the potential for the market to act on the information in advance of the release and this certainly seems to be the case in this situation.

Perhaps, the most surprising fining of all is the collapse in returns almost immediately after the release of the information which is the case for all three types of announcements. This is the differentiating feature when using the market reaction to earnings announcements as the benchmark against which to judge our results. With earnings results, there is a clear post-announcement drift in the same direction as both the pre-announcement drift and the market reaction during the announcement period. Much work has been undertaken on the PEAD which fails to provide any rational explanation for this on-going anomaly. Now we have a different situation where the market seems to consistently misinterpret the information released by mining companies up to the announcement date but then quickly begins to realise the error in its ways as evidenced by a market correction which typically commences the day after the announcments but then continues on for an extended period. The final result being that all three informational releases have almost no effect on market prices over our 91-day event window suggesting that the market takes them as having no consequence. This is indeed a strange outcome given that one would perceive that the identification of valuable mining claims as being the driving force in the valuation of these companies. The results suggest to us the need for further research to try and identify the reasons for the market seemingly been fooled by these announcments which should extend to evaluating the veracity of the information

The summary to date has only addressed the overall results but we divided our sample up into separate sub-samples on the basis of size, frequency of trading and also revenue generation. For the exploration and the resource announcments, there was a significant positive market reaction as at the time of the release across all of the sub-samples. Further, there was no significant reaction in any of the sub-samples to the resource announcments. All of the differences in the reaction across the sub-samples occur in the pre- and postannouncement periods.

In the case of the exploration announcments, the pre-announcement anticipation is much greater for the larger, higher frequency trading companies that are yet to generate any revenue. With respect to the resource announcments, the results are similar in that the larger anticipation comes in the larger, higher frequency trading companies that are already generating revenue. However, the results are very different for the reserve announcements where the greatest anticipation is in the smaller, low frequency trading companies that are yet to generate revenue. In summary then there is a greater anticipation problem for the more established companies with respect to the exploration and resource announcements but for the junior mining companies with respect to the reserve announcements. When we turn to the post-announcement correction, the findings are similar to those for the preannouncement anticipation but only stronger. It is the junior mining companies that experience by far the greatest correction after the announcement. Indeed during the post announcement period, the accumulative abnormal returns are fairly steady for the better established mining companies making exploration or resource announcements. However, again these findings reverse in the case of the reserve announcements where it is the more 
established companies that go into something akin to free fall after the release of the information.

This paper represents a first attempt to gauge the market reaction to exploration, resource and reserve announcments by mining companies. We have been able to identify several interesting results which should open up further research opportunities especially with respect to the market reaction to announcments by mining companies during the pre- and post-announcement periods. The regulators should be concerned by both the high level of market anticipation of all three types of announcements and also the fact that the market would seem to regularly misinterpret the information content of these announcments. Further, the paper provides yet another challenge to those who maintain that capital markets are informationally efficient. We look forward to seeing the outcome of further studies in what has been a hugely under-researched area.

\section{References}

ABS, 2008, 'Australian Bureau of Statistics, Australian Industry 2007-2008', ASX. 2009, 'Resource Sector’ viewed $3^{\text {rd }}$ September 2009, http://www.asx.com.au/research/industry/mining/index.htm ASX, 2009A, ‘ASX Listing Rules', viewed $3^{\text {rd }}$ September 2009, $<$ http://www.asx.com.au/supervision/rules_guidance/listing_rules1.htm>

Ball, R. 1978, 'Anomalies in Relationships Between Securities' Yields and YieldSurrogates', Journal of Financial Economics, vol. 6, pp. 103-126.

Ball, R. and Brown, P. 1968, 'An empirical evaluation of accounting income numbers', Journal of Accounting Research, vol. 6, pp.159-178.

Barber, B. and Lyon, J. 1997, 'Detecting long-run abnormal stock returns: the empirical power and specification of test statistics, Journal of Financial Economics, Vol. 43, pp. 341372.

Bartov, E. Radhakrishnan, S. and Krinsky, I. 2000, 'Investor sophistication and patterns in stock returns after earnings announcements', Accounting Review, vol. 75, pp. 43-63.

Bebos, A., and Rockinger, M. 2000, 'Market Response to earnings Announcdements and Interim Reports: An Analysis of SBF120 Companies’, Annales et de Statistique, Vol. 60, pp.

Bernard, V. and Thomas, J. 1989, 'Post-earnings-announcement drift: delayed price response of risk premium?’, Journal Accounting Research, vol. 27 pp. 1-48.

Bernard, V. and Thomas, J. 1990, 'Evidence that stock prices do not fully reflect the implications of current earnings for future earnings', Journal Accounting Economics, vol.13, pp. 305-341.

Boone, J. 1998, 'Oil and gas reserve value disclosures and the bid-ask spread', Journal of Accounting and Public Policy, vol.17, pp. 55 - 84.

Brown, O. and Burdekin, R. 2000, 'Fraud and Financial markets: The 1997 Collapse of the Junior Mining Stocks', Journal of Economics and Business vol. 52 pp.277-288

Brown, S,J. and Warner, J,B. 1985, 'Using Daily Stock Returns: The Case of Event Studies,' Journal of Financial Economics, 14 (1985), 3-31.

Brown, p. 1970. 'The impact of the annual report on the stock market:' The Australian Accountant, pp. 277 - 283.

Brown, P., Fergusaon, A.,, and Stone, K. 2008, 'Share Purchase Plans in Australia: Issuer Characteristics and Valuation Implications', Australia Journal of Management, vol. 33, pp. $307-331$.

Chordia, T., Goyal A., Sadka, G., Sadka, R., and Shivakumar, L. 2009, 'Liquidity and the Post- Earnings- Announcement Drift', Financial Analysts Journal, vol. 65, pp. 18 - 32. Clinch, G. and Magliolo, J. 1992, "Market Perceptions of reserve Disclosures Under SFAS No. 69', The Accounting Reviewvol.67, pp 843 - 861. 
Czernkowski, R and Ferguson, A. 2006, 'Information asymmetry resolution in the Australian Mining Industry' The Accounting and Finance Association of Australia and New Zealand, viewed $2^{\text {nd }}$ July 2009, http://www.afaanz.org/openconf/afaanz/paper.php?p=261.doc

Dumay, J. and Tull, J. 2007, 'Intellectual capital disclosure and price-sensitive Australian Stock Exchange announcements’ Journal of Intellectual Capital, Vol 8, no. 2, pp.236-255. Falk, H, and Levy H. 1989, 'Market Reaction to Quarterly Earnings Announcements: A Stochastic Dominance Based Test of Market Efficiency’ Manage Science, vol. 35, pp. 425 - 446.

Fama, E. 1998, 'Market efficiency, long-term returns, and behavioural finance', Journal of Financial Economics, vol.49, pp. 283-306.

Ferguson, A. and Crockett, A. 2003, 'Information transfer and press coverage: The case of the Gawler Craton gold boom’, Pacific Basin Finance Journal 1, 101-120.

Firth, M. 1981, 'The relevant information content of the release of financial results data by firms’ Journal of Accounting Research, vol. 19, pp. 521 - 529.

Foster, G. Olsen, C and Shevlin, T. 1984, 'Earnings Releases, Anomalies, and the Behaviour of Security Returns' The Accounting Review, Vol. LIX, No 4, pp. 574-603.

Harris, t, and Ohlson, J. 1990, 'Accounting Disclosure and the market Valuation of Oil and Gas Properties: Evaluation of market Efficiency and Functional Fixation”, The Accounting Review, Vol. 65, pp. $764-780$.

Hellbling, T. and Blackman, V. 2008, 'Commodity Price Moves and the Global Economic Slowdown', IMFSurvey Magazine: IMF Research, 20 ${ }^{\text {th }}$ March 2008, viewed 11th November 2009, http://imf.org/external/pubs/ft/survey/so/2008/RES032008A.htm How, J. 2008, 'Initial and Long-run Performance of Mining IPOs in Australia', Australian Journal of Management, Vol. 25, pp.95-108.

ICM, 2009, 'Industry Classification Benchmark, a single standard defining the market', viewed 6th October 2009, <http://www.icbenchmark.com/>

Jara, J. Lagos, G. and Tilton, J. 2008, 'Using exploration expenditure to asses the climate for mineral investment', Resources Policy, Vol.33, pp. 179-187.

JORC, 2004, 'The 2004 Australasian Code for Reporting Exploration Results, Mineral Resources and Ore Reserves', prepared by The Joint Ore Reserves Committee of The Australian Institute of Mining and Metallurgy, Australian Institute of Geoscientist and Minerals Council of Australia.

Kallinki, J. 1997, 'Handling Missing Prices in Thinly Traded Stock Market: Implications for the Specification of Event Study Methods', European Journal of Operational Research' vol. 103 pp. 186 - 197.

Kennedy, J., 1996. 'A performance model for mineral exploration companies', Unpublished PhD Thesis, University of Queensland, Brisbane, 298pp.

Kennedy, J., 1997. 'Size at listing and performance of new mineral exploration companies', Proceedings of the Annual Conference of the Small Enterprise Association of Australia and New Zealand, Coffs Harbour, pp. 347-354.

Kreuzer, O. Etheridge, M. and Guj, P. 2007, 'Australian Junior Exploration Floats, 2001 2006, and their implications for IPO’s’, Resources Policy Journal 32, 159-182.

Leemakdej, A., 2009, 'Detecting Abnormal Returns of Infrequently Traded Stocks in an Event Study’, Available at SSRN: http://ssrn.com/abstract=1436090

Magliolo, J. 1986'Capital Markey Analysis of Reserve Recognition Accounting', Journal of Accounting Research, Vol. 24, pp. 69 - 108.

Magness, V. 2009, “A tale of two signals: Environmental disclosure in the Canadian mining industry”, Ryerson University Working Paper

Meek, G. 1991, 'Capital Market Reactions to Accounting Earnings Announcements in an International Context', Journal of International Financial Management and Accounting, vol 3, pp. $93-109$. 
Metals Economics Group, 2009, 'World Exploration Trends' viewed $5^{\text {th }}$ October 2009, $<$ http://www.metalseconomics.com/pdf/PDAC\%202009\%20World\%20Exploration\%20Tr ends.ppd>

Mohn, K. 2008, ' Efforts and Efficiency in Oil Exploration: A Vector Error-Correction Approach', The Energy Journal, Vol.29, no.4, pp.53-78.

O’Shea P., Worthington, A., Griffiths, D., and Gerace, D. 2008, 'Paters and disclosure and the volatility effects in speculative industries', Journal of Financial Regulation and Compliance, vol 16. pp. 261 - 273.

Ritter, J. 1991, 'The Long-Run Performance of Initial Public Offerings', The Journal of Finance, Vol. XLVI, no. 1, pp. 3-27.

Schwert, G. 2003, 'Anomalies and Market Efficiency” in Constantinides, G., Harris, M., and Stulz, R. (ed.) Handbook of the Economics of Finance North-Holland Amsterdam Soffer, L., Thiagarajan, S., and Walther, B. 2000, 'Earnings Preannouncement Strategies', Review of Accounting Studies, vol. 5, pp. 5 - 26

Soffer, L. 2001, 'Market Reaction to Repeat Preannouncements', Managerial Finance, vol. 27, pp. $40-56$.

Tufano, P. 1998, 'The determinants of stock price exposure: Financial engineering and the gold mining industry', Journal of Finance, vol. 53, pp. 1015- 1052.

Watts, R. 1978, 'Ststematic 'Abnormal’ Returns After Quarterly Earnings Announcement', journal of Financial Economics, pp. 127 - 150. 